\title{
White spot disease risk factors associated with shrimp farming practices and geographical location in Chanthaburi province, Thailand
}

\author{
Patharapol Piamsomboon, Chaidate Inchaisri, Janenuj Wongtavatchai* \\ Department of Veterinary Medicine, Faculty of Veterinary Science, Chulalongkorn University, Pathumwan, Bangkok 10330, \\ Thailand
}

\begin{abstract}
Over the past 2 decades, shrimp aquaculture in Thailand has been impacted by white spot disease (WSD) caused by white spot syndrome virus (WSSV). Described here are results of a survey of 157 intensive shrimp farms in Chanthaburi province, Thailand, to identify potential farm management and location risk factors associated with the occurrence of WSD outbreaks. Logistic regression analysis of the survey responses identified WSD risks to be associated with farms sharing inlet water and culturing shrimp year round and with a single owner operating more than 1 farm. The analysis also showed WSD risks to be reduced at farms that used probiotics and applied lime to pond bottoms when fallow to neutralize acidity and kill microorganisms. Regression modeling identified no association of geographical location with WSD. The data should assist shrimp farms in mitigating the effects of WSD in Thailand.
\end{abstract}

KEY WORDS: Epidemiology · Risk factors · Shrimp farming - Thailand · White spot disease · WSSV $\cdot$ Pacific white shrimp $\cdot$ Litopenaeus vannamei

\section{INTRODUCTION}

White spot disease (WSD) is caused by white spot syndrome virus (WSSV), which has been responsible for substantial economic losses to shrimp farming industries in most parts of the world. WSSV has a wide host range, including most freshwater or marine decapod crustaceans and all commercially important cultured shrimp species (OIE 2014). WSD can result in up to $100 \%$ farm pond mortality within 3 to 10 d (Nunan et al. 2001) and was first reported in Taiwan and China in 1992 before spreading to become pandemic within a decade (Dieu et al. 2010, Vijayan \& Sanil 2012). In Thailand, WSD outbreaks were first reported in 1995 (Flegel 1997), and the virus rapidly became endemic throughout shrimp farming areas.

As no resistant shrimp or effective commercial treatment options for WSD are currently available, disease control and prevention have relied mainly on management strategies, including virus exclusion and reducing shrimp stress (OIE 2014). Control measures for reducing the incidence of WSD currently rely on stocking ponds with WSSV-free postlarvae, using closed zero-water-exchange culture systems and/or biosecure ponds incorporating crabproof fencing and bird-proof netting as well as disinfectant systems for workers' hands and feet (Corsin et al. 2005). Despite the availability of such risk mitigation methods, WSD still occurs widely and poses a major threat to shrimp farming industries throughout Asia and elsewhere (Flegel 2012).

Identifying disease risk factors can help devise management practices that are effective in reducing the impact of aquatic animal diseases (Peeler \& Taylor 2011). Farm location and management practices can influence the incidence of WSD. For example, a study in the Philippines identified high stocking den- 
sities, the feeding of live mollusks, farm sharing of water sources, and increased pond size to be associated with increased WSD risks (Tendencia et al. 2011). Other studies identified increased mangrove to pond area ratios, the use of vitamin dietary supplements, water filtration through $300 \mu \mathrm{m}$ mesh screens, and pond bottom dry-out and decontamination, including plowing and sludge removal between crops, as factors that reduce WSD risks (Corsin et al. 2005, Tendencia et al. 2011).

Risk analyses can be instructive as to what measures might assist in mitigating disease impacts in a particular farming region. The purpose of this study was thus to identify risk factors associated with the occurrence of WSD in Chanthaburi province, an intensive shrimp aquaculture region in Thailand, so that these might be used to guide government and farm WSD control policies.

\section{MATERIALS AND METHODS}

\section{Study population and size}

The study focused on Pacific white shrimp Litopenaeus vannamei farms located in the coastal area of Chanthaburi province, Thailand (Fig. 1) and was conducted between October 2011 and December
2013 in collaboration with the Chanthaburi Coastal Fisheries Research and Development Centre (CFRD), Department of Fisheries. Chanthaburi province is among the largest shrimp aquaculture regions in Thailand, producing >60000 $\mathrm{t} \mathrm{yr}^{-1}$ (Department of Fisheries 2014). Farmers generally purchase shrimp postlarvae age 10 to $12 \mathrm{~d}$ (PL10-PL12) from local or nearby $(<300 \mathrm{~km})$ hatcheries for grow-out in earthen ponds for 90 to $120 \mathrm{~d}$.

The case-control study used a questionnaire to interview farmers (the full questionnaire is provided in the Supplement, available at www.int-res.com/ articles/suppl_d117p145_supp.pdf). Farms were selected arbitrarily from 886 farms located in the CFRD study area. Farms were divided into WSD case and control groups based on their disease status in CFRD records. WSSV was detected using the nested PCR method endorsed by the World Organization for Animal Health (OIE 2014). Farms were assigned to the WSD case group when WSSV was detected in association with disease in at least 1 crop over the study period. Farms were assigned to the control group when monthly samples were WSSV-negative over the study period. Based on assuming an odds ratio (OR) of 4 with a 95\% confidence interval (CI) and $80 \%$ statistical power with an expected proportion exposed amongst controls of $8 \%$, at least 66 farms were required per group. A farm sample size of 100

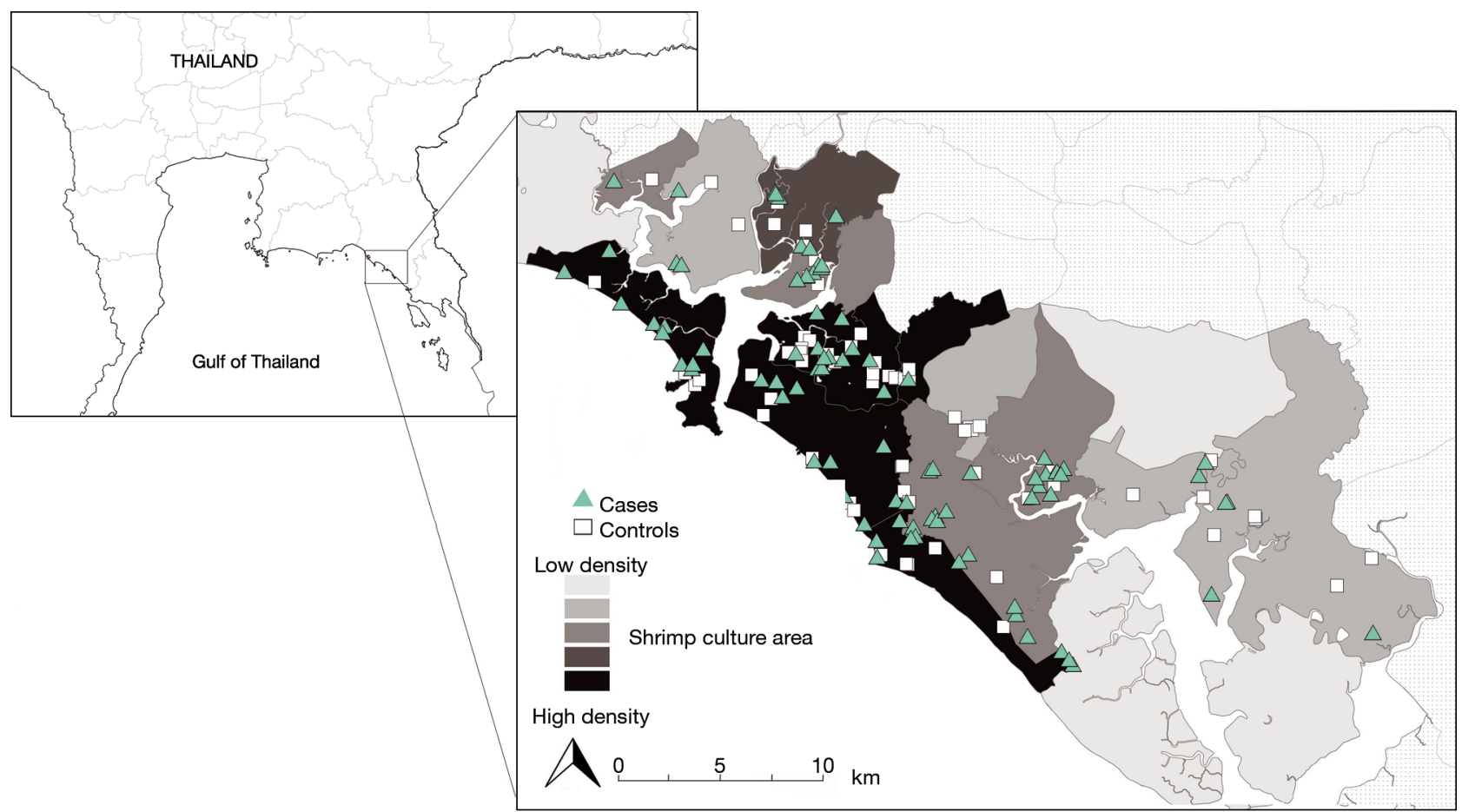

Fig. 1. Study area in Chanthaburi province, Thailand. Locations of case ( $\triangle$ ) and control ( $\square$ ) farms are shown. Map shading shows farm densities from lowest (light grey) to highest (black) 
for both the case and control groups was therefore selected for the interviews.

\section{Information collection}

Information on farming practices was collected using a structured farm owner questionnaire combined with interviewer observations (see the Supplement). The questions were approved by local government officers and farm personnel to ensure they were easily understood. For consistency, all farm owners and/or managers were interviewed by $\mathrm{P}$. Piamsomboon on the basis that their responses would be anonymous. Questions on potential risk factor variables covered farm characteristics and management practices as well as various other factors described in studies in other Asian countries (Tendencia et al. 2011, Table 1).

Farm global positioning system (GPS) $x, y$ coordinates were obtained using a Garmin eTrex ${ }^{\circledR} 10$ handheld GPS device. For each farm, distances to the nearest point on the coastline, public canal, national highway, and mangrove forest were determined using the Euclidean distance calculation function in the Spatial Analyst Tools, ArcToolbox, ArcGIS 10.0 software (ESRI). The relevant spatial data of road networks, coastline, canals, and mangrove forests were provided by the Royal Thai Survey Department, Ministry of Defense.

\section{Statistical analysis}

Statistical analyses utilized SPSS software (version 22). Continuous-scale risk factor variables were tested for normality and linearity of effect. If the distribution was not normal or linear, the variable was transformed to a categorical scale using quartiles. The WSD status of the farm was used as the dependent variable in each analysis. Univariate logistic regression was initially performed in order to identify a subset of statistically significant risk factor variables using $\mathrm{p}<0.1$. Spearman rank correlations were used to examine for collinearity between the significant risk factor variables. Correlation coefficients $>0.4$ were interpreted to indicate collinearity. Amongst pairs of collinear variables, a choice was made based on acceptability of potential biological cause-effect relationships to select the variable to include in the multivariable analysis. Subsequently, variables that were not collinear were included in a multivariable logistic regression analysis using a backward stepwise variable selection approach based on $\mathrm{p}>0.05$. ORs and their $95 \%$ CIs were calculated for statistically significant risk factor variables. Variables that changed the regression coefficient estimates of at least 1 other variable in the model by more than $20 \%$ were considered to be confounders and therefore included in the final model to adjust for the confounding effect of that risk factor.

\section{RESULTS}

\section{Descriptive analysis}

Of the 200 farms that had been in operation for at least $5 \mathrm{yr}$ and were selected for study, 157 (comprising 88 case-group farms and 69 control-group farms) agreed to be interviewed. These included 87 (55.4\%) small farms, 46 (29.3\%) intermediate-sized farms, and $24(15.3 \%)$ large farms (Table 1). The total culture area covered by the farms represented $25.1 \%$ of that in Chanthaburi province.

In terms of farm biosecurity, $26.2 \%$ were fenced and $6.4 \%$ had vehicle tire baths and personnel disinfection systems at their entrance. At most (77\%) farms, water was released directly into the environment at harvest rather than being recycled. Very few $(<1 \%)$ farms practiced water decontamination prior to release. Many (42\%) farms had crab-proof fencing and $27.4 \%$ had bird-proof netting.

\section{Univariate and multivariate analyses}

The univariate analysis identified 15 risk factors for inclusion in the multivariable analysis (Table 1). The final model initially comprised 6 variables: water source, continuous culture throughout the year, owner of multiple farms, lime application, use of probiotics, and presence of a caretaker. Of these variables, significant correlations were found between caretaker and water source $(r=0.54)$ and between caretaker and continuous culture $(\mathrm{r}=0.46)$. The water source and continuous culture variables were thus selected for the final model because they had previously been identified as potential WSD risk factors (Tendencia et al. 2011). The reintroduction of the 'distance to national highways' variable resulted in a $>20 \%$ change in 1 category coefficient estimate for the water source variable, and it was thus included as a confounder in the model. The $95 \%$ CI, OR and level of statistical significance for each variable are detailed in Table 2. 
Table 1. Results of the univariate logistic regression analysis of the association between white spot disease (WSD) occurrence in cultured Pacific white shrimp Litopenaeus vannamei and farm characteristics and farm management factors. Values in bold indicate $\mathrm{p}<0.1 ; \mathrm{N}$ : number of farms; OR: odds ratio; Ref.: reference groups. ${ }^{*}$ Asterisks indicate risk factors $(\mathrm{p}<0.1)$. Quartiles are ranked sets of continuous data equally divided into 4 groups

\begin{tabular}{|c|c|c|c|c|c|}
\hline Variable & Explanation & & $\mathrm{N}$ & $\mathrm{p}$ & OR \\
\hline \multicolumn{6}{|l|}{ Farm area } \\
\hline \multirow[t]{4}{*}{ Farm size } & Total farm area (ha) & & & & \\
\hline & $<2.4$ & & 87 & 0.15 & 0.48 \\
\hline & $>2.4-8$ & & 46 & 0.76 & 0.85 \\
\hline & $>8$ & & 24 & Ref. & Ref. \\
\hline \multirow[t]{4}{*}{ Culture area* } & Total area used for shrimp culture (ha) & & & & \\
\hline & $<0.88$ & & 39 & 0.01 & 0.31 \\
\hline & $>0.88-4.32$ & & 80 & 0.09 & 0.49 \\
\hline & $>4.32$ & & 38 & Ref. & Ref. \\
\hline \multirow[t]{5}{*}{ Water reserve area* } & Total area of reservoir pond (ha) & & & & \\
\hline & 0 & & 52 & 0.85 & 0.92 \\
\hline & $>0-0.32$ & & 44 & 0.44 & 0.71 \\
\hline & $>0.32-1.04$ & & 22 & 0.01 & 1.50 \\
\hline & $>1.04$ & & 39 & Ref. & Ref. \\
\hline \multirow[t]{5}{*}{ Sludge pond area* } & Total area of sludge pond (ha) & & & & \\
\hline & 0 & & 47 & 0.88 & 0.93 \\
\hline & $>0-0.16$ & & 42 & 0.04 & 0.39 \\
\hline & $>0.16-0.48$ & & 31 & 0.57 & 1.33 \\
\hline & $>0.48$ & & 37 & Ref. & Ref. \\
\hline \multicolumn{6}{|l|}{ Farm features } \\
\hline \multirow[t]{3}{*}{ No. of ponds farm ${ }^{-1}$} & Total no. of ponds used for shrimp culture farm ${ }^{-1}$ & & & & \\
\hline & $\leq 10$ & & 127 & 0.17 & 0.57 \\
\hline & $>10$ & & 30 & Ref. & Ref. \\
\hline Cul:res ratio* & Ratio between shrimp culture and reservoir pond area & & Ref. & 0.03 & 1.03 \\
\hline \multirow[t]{4}{*}{ Caretaker* } & Person responsible for farm operation: & & & & \\
\hline & Owner & & 80 & 0.04 & 0.42 \\
\hline & Owner and worker(s) & & 39 & 0.07 & 0.42 \\
\hline & Farm manager and worker(s) & & 38 & Ref. & Ref. \\
\hline \multirow[t]{4}{*}{ Water source ${ }^{*}$} & Source of water used in farm for shrimp culture: & & & & \\
\hline & Sea & & 23 & 0.36 & 1.8 \\
\hline & Public canal(s) & & 117 & 0.01 & 3.98 \\
\hline & Underground water & & 17 & Ref. & Ref. \\
\hline \multirow[t]{2}{*}{ Owner of multiple farms* } & Farmer operates more than 1 farm, each located & Yes & 48 & 0.06 & 1.89 \\
\hline & in different areas & No & 109 & Ref. & Ref. \\
\hline \multirow[t]{2}{*}{ Water recycling } & Reuse of water from the previous shrimp crop to & Yes & 36 & 0.22 & 0.63 \\
\hline & culture the next crop & No & 121 & Ref. & Ref. \\
\hline \multirow[t]{2}{*}{ Adjacent farms } & Presence of other shrimp farms next to the observed farm & Yes & 138 & 0.19 & 1.8 \\
\hline & & No & 19 & Ref. & Ref. \\
\hline \multirow[t]{2}{*}{ Limited access } & No access of unauthorized personnel to farm & Yes & 59 & 0.98 & 0.99 \\
\hline & & No & 98 & Ref. & Ref. \\
\hline \multirow[t]{2}{*}{ Fence } & Presence of barrier or other upright structure & Yes & 41 & 0.27 & 1.5 \\
\hline & surrounding the farm & No & 116 & Ref. & Ref. \\
\hline \multirow[t]{2}{*}{ Pets in farm } & Presence of other animals roaming freely in the farm, & Yes & 69 & 0.45 & 1.27 \\
\hline & e.g. dogs and chickens & No & 88 & Ref. & Ref. \\
\hline \multirow[t]{2}{*}{ Vehicle disinfection } & Disinfection processes used for vehicles entering & Yes & 10 & 0.32 & 1.90 \\
\hline & the farm, e.g. tire baths and vehicle sprays & No & 147 & Ref. & Ref. \\
\hline \multirow[t]{2}{*}{ Separate workers } & Different worker allocated to each pond & Yes & 39 & 0.95 & 1.02 \\
\hline & & No & 118 & Ref. & Ref. \\
\hline \multirow[t]{2}{*}{ Continuous culture* } & Farm that stocks shrimp continuously year round, & Yes & 86 & 0.08 & 1.73 \\
\hline & producing more than 2 crops per year & No & 71 & Ref. & Ref. \\
\hline Pond preparation & & & & & \\
\hline Sludge removal & Disposal of soil at the bottom of the pond after & Yes & 82 & 0.52 & 0.81 \\
\hline & each crop is harvested & No & 75 & Ref. & Ref. \\
\hline Lime application* & Application of lime to dried pond bottom for disinfection & Yes & 57 & 0.01 & 0.49 \\
\hline & & No & 100 & Ref. & Ref. \\
\hline
\end{tabular}


Table 1 (continued)

\begin{tabular}{|c|c|c|c|c|c|}
\hline Variable & Explanation & & $\mathrm{N}$ & $\mathrm{p}$ & OR \\
\hline \multicolumn{6}{|l|}{ Water preparation } \\
\hline \multirow{2}{*}{ Water filter } & \multirow[t]{2}{*}{ Water in culture ponds is filtered using a trawling net } & Yes & 105 & 0.52 & 0.80 \\
\hline & & No & 52 & Ref. & Ref. \\
\hline \multirow[t]{2}{*}{ Animal waste } & \multirow[t]{2}{*}{ Chicken/pig manure or cow dung used as pond fertilizer } & Yes & 53 & 0.92 & 1.03 \\
\hline & & No & 104 & Ref. & Ref. \\
\hline \multirow[t]{2}{*}{ Inorganic fertilizer } & \multirow{2}{*}{$\begin{array}{l}\text { Use of inorganic fertilizer to adjust water color before } \\
\text { stocking shrimp }\end{array}$} & Yes & 99 & 0.87 & 0.94 \\
\hline & & No & 58 & Ref. & Ref. \\
\hline \multirow[t]{2}{*}{ Insecticide } & \multirow{2}{*}{$\begin{array}{l}\text { Use of insecticide to eliminate aquatic decapods } \\
\text { during water preparation }\end{array}$} & Yes & 108 & 0.78 & 1.09 \\
\hline & & No & 49 & Ref. & Ref. \\
\hline \multirow[t]{2}{*}{ Copper } & \multirow{2}{*}{$\begin{array}{l}\text { Use of copper to eliminate shellfish before } \\
\text { stocking shrimp }\end{array}$} & Yes & 101 & 0.54 & 0.81 \\
\hline & & No & 56 & Ref. & Ref. \\
\hline \multirow[t]{2}{*}{ Tea seed* } & \multirow{2}{*}{$\begin{array}{l}\text { Use of tea seed cakes or powder to kill small fish } \\
\text { before stocking }\end{array}$} & Yes & 138 & 0.07 & 0.34 \\
\hline & & No & 19 & Ref. & Ref. \\
\hline \multicolumn{6}{|l|}{ Pond features } \\
\hline \multirow[t]{2}{*}{ PE-lined pond } & \multirow[t]{2}{*}{ Use of polyethylene (PE) to cover the pond slope } & Yes & 74 & 0.42 & 1.29 \\
\hline & & No & 83 & Ref. & Ref. \\
\hline \multirow[t]{2}{*}{ Bird-proof netting } & \multirow{2}{*}{$\begin{array}{l}\text { String or net installed above the pond to prevent } \\
\text { access by birds }\end{array}$} & Yes & 43 & 0.69 & 0.86 \\
\hline & & No & 114 & Ref. & Ref. \\
\hline Crab-proof fencing & Nylon/plastic screen installed on dike surrounding the & Yes & 66 & 0.74 & 0.90 \\
\hline & pond to prevent crabs from entering & No & 91 & Ref. & Ref. \\
\hline Hand and foot baths & Containers placed at pond entrance that contain & Yes & 24 & 0.18 & 2.12 \\
\hline & chemicals for disinfection of workers' hands and feet & No & 133 & Ref. & Ref. \\
\hline Feed additive & & & & & \\
\hline Vitamin C & Use of commercial vitamin $\mathrm{C}$ mixed into feed & Yes & 22 & 0.75 & 1.27 \\
\hline & & No & 135 & Ref. & Ref. \\
\hline Probiotics mix in feed ${ }^{*}$ & Use of commercial probiotics mixed into feed & Yes & 136 & 0.05 & 0.35 \\
\hline & & No & 21 & Ref. & Ref. \\
\hline Postlarvae (PL) & & & & & \\
\hline Source of shrimp $\mathrm{PL}^{*}$ & Provinces from which farmers obtain PL & & & & \\
\hline & Province 1 & & 63 & 0.03 & 0.41 \\
\hline & Province 2 & & 47 & 0.50 & 0.73 \\
\hline & Province 3 & & 43 & Ref. & Ref. \\
\hline Virus detection of PL & Test for abnormalities and the presence of important & Yes & 88 & 0.91 & 0.96 \\
\hline & viruses in PL before stocking & No & 69 & Ref. & Ref. \\
\hline Stocking density & No. of PL released to culture pond (PL m ${ }^{-2}$ ) & & & & \\
\hline & $<62.5$ & & 80 & 0.33 & 0.62 \\
\hline & $>62.5-81.25$ & & 40 & 0.92 & 1.05 \\
\hline & $>81.25$ & & 37 & Ref. & Ref. \\
\hline Distance variables $^{\mathrm{a}}$ & Nearest distance categorized into quartiles from farms to & partic & Ir feat & $\mathrm{es}(\mathrm{km})$ & \\
\hline To coastline ${ }^{*}$ & Quartile $1(0.03-0.58)$ & & 39 & 0.17 & 1.86 \\
\hline & Quartile $2(0.60-1.26)$ & & 39 & 0.01 & 4.07 \\
\hline & Quartile $3(1.27-2.34)$ & & 39 & 0.72 & 2.30 \\
\hline & Quartile 4 (2.35-6.44) & & 39 & Ref. & Ref. \\
\hline To nearest national & Quartile $1(0.01-1.00)$ & & 39 & 0.01 & 0.29 \\
\hline highway* & Quartile 2 (1.09-2.09) & & 39 & 0.99 & 0.44 \\
\hline & Quartile $3(2.13-4.16)$ & & 39 & 0.01 & 0.29 \\
\hline & Quartile 4 (4.17-9.51) & & 39 & Ref. & Ref. \\
\hline To nearest public canal & Quartile 1 (0.06-0.38) & & 39 & 0.49 & 0.73 \\
\hline & Quartile $2(0.39-0.85)$ & & 39 & 0.24 & 1.73 \\
\hline & Quartile $3(0.86-1.85)$ & & 39 & 0.49 & 0.73 \\
\hline & Quartile 4 (1.86-5.68) & & 39 & Ref. & Ref. \\
\hline To nearest mangrove & Quartile 1 (0.01-1.00) & & 39 & 0.29 & 0.61 \\
\hline forest* ${ }^{*}$ & Quartile 2 (1.09-2.09) & & 39 & 0.74 & 1.16 \\
\hline & Quartile 3 (2.13-4.16) & & 39 & 0.08 & 0.45 \\
\hline & Quartile 4 (4.17-9.51) & & 39 & Ref. & Ref. \\
\hline
\end{tabular}


Table 2. Final logistic regression model of white spot disease (WSD) risk factors in intensive Pacific white shrimp Litopenaeus vannamei culture systems in Chanthaburi province, Thailand. N: number of farms; $\beta$ : estimated coefficient; CI: confidence interval; Ref.: reference group of each variable

\begin{tabular}{|c|c|c|c|c|c|}
\hline \multirow{2}{*}{$\begin{array}{c}\text { Parameter } \\
\text { Variable }\end{array}$} & \multirow[t]{2}{*}{$\mathrm{N}$} & \multirow[t]{2}{*}{$\beta$} & \multicolumn{2}{|c|}{ Odds ratio } & \multirow[t]{2}{*}{$\mathrm{p}$} \\
\hline & & & Value & $95 \%$ CI & \\
\hline Constant & & 0.23 & 1.26 & $0.2-7.83$ & 0.8 \\
\hline \multicolumn{6}{|l|}{ Water source } \\
\hline Sea & 23 & -0.68 & 0.5 & $0.08-3.09$ & 0.46 \\
\hline Canal & 117 & 1.15 & 3.16 & $0.95-10.57$ & 0.05 \\
\hline Undergrounc & 17 & Ref. & Ref. & Ref. & Ref. \\
\hline \multicolumn{6}{|c|}{ Lime application } \\
\hline Yes & 57 & -0.99 & 0.37 & $0.16-0.86$ & 0.02 \\
\hline No & 100 & Ref. & Ref. & Ref. & Ref. \\
\hline \multicolumn{6}{|c|}{ Probiotic used in feed } \\
\hline Yes & 136 & -1.54 & 0.21 & $0.06-0.72$ & 0.01 \\
\hline No & 21 & Ref. & Ref. & Ref. & Ref. \\
\hline \multicolumn{6}{|c|}{ Owner of multiple farms } \\
\hline Yes & 48 & 1.4 & 4.05 & $1.41-11.64$ & 0.01 \\
\hline No & 109 & Ref. & Ref. & Ref. & Ref. \\
\hline \multicolumn{6}{|c|}{ Year round continuous culture } \\
\hline Yes & 86 & 0.83 & 2.29 & $0.99-5.28$ & 0.05 \\
\hline No & 71 & Ref. & Ref. & Ref. & Ref. \\
\hline \multicolumn{6}{|c|}{ Distance from the nearest national highway } \\
\hline Quartile 1 & 39 & -1.02 & 0.36 & $0.12-0.96$ & 0.05 \\
\hline Quartile 2 & 39 & -0.89 & 0.40 & $0.12-1.30$ & 0.12 \\
\hline Quartile 3 & 39 & -1.11 & 0.33 & $0.1-1.08$ & 0.06 \\
\hline Quartile 4 & 39 & Ref. & Ref. & Ref. & Ref. \\
\hline
\end{tabular}

\section{DISCUSSION}

WSSV has been a cause of serious disease in shrimp farmed in Thailand and has impacted both black tiger shrimp Penaeus monodon and Pacific white shrimp in hatcheries as well as in grow-out ponds (Withyachumnarnkul et al. 2003, Flegel 2012). Control of WSD in Thailand has been challenging because small- to medium-scale farms make up a large part of the industry. These farms are usually clustered, share common water sources, and disregard recommended disease management practices. Despite strict biosecurity measures being used actively at the large-scale study farms, WSD remains an issue because biosecurity is neglected at neighboring small-scale farms. Better management practices (BMPs) have been introduced to small-scale aquaculture farms in many developing countries (Mohan et al. 2008, Phan et al. 2009, Umesh et al. 2010). These BMPs aim to provide small-scale farmers with knowledge of inexpensive and practical farm management and feeding procedures to assist them in improving yields and minimize losses caused by infectious dis- eases (Padiyar et al. 2003). In India, BMPs have been implemented in shrimp culture communities affected seriously by WSD, and risk factor analyses have been pivotal to identifying and quantifying the value of various BMPs (Padiyar et al. 2003, Mohan \& De Silva 2010).

In the Chanthaburi province study area, WSD occurrence was associated profoundly with the sourcing of pond water from communal canals conveying water to a cluster of farms from either the sea or a river. This has also been identified as an important WSD risk factor in the Philippines, particularly when the canal is used for both farm inlet and outlet water, and more so when used as a water outlet during emergency harvests (Tendencia et al. 2011). At all of our study farms, however, canal inlet water was typically chlorinated before being used to fill ponds, and all employed zero water exchange grow-out systems. However, not all farms applied pond biosecurity systems to prevent entry of WSSV carriers likely to reside in the communal canals, and thus such carriers might represent a source of disease (OIE 2014). WSD outbreaks in farms in Vietnam have been associated with the introduction of WSSV-infected decapods and WSSV-contaminated zooplankton (Corsin et al. 2001). The use of communal canals also increases the likelihood of ponds receiving poorquality hypertrophic or eutrophic water with potential to cause stress that could in turn induce disease (Lyle-Fritch et al. 2006, Huang et al. 2011).

In the study area, shrimp farms most distant from highways tended to be those either using or located nearest to communal canals. Therefore, this variable was also correlated with higher farm densities and WSD occurrence. The higher risk of WSD at farms where the owner operated several farms might be due to increased movements of staff and vehicles between the farms together with inadequate biosecurity precautions.

Experienced shrimp farmers in Thailand and the Philippines generally avoid stocking ponds during colder weather due to higher risks of WSD (Withyachumnarnkul et al. 2003, Tendencia et al. 2010). Higher WSD risks do occur at farms growing 3 or more crops each year compared to farms growing fewer than 2 crops during the warmer months. WSD becomes less problematic in grow-out water temperatures above $30^{\circ} \mathrm{C}$, and WSSV has been identified to replicate more effectively in Pacific white shrimp at water temperatures of $\sim 26^{\circ} \mathrm{C}$ compared to $\sim 32^{\circ} \mathrm{C}$ (Vidal et al. 2001). These findings are supported by WSSV gene expression in subcuticular epithelial cells being higher among Pacific white shrimp in 
$\sim 26^{\circ} \mathrm{C}$ water compared with $33^{\circ} \mathrm{C}$ water (Reyes et al. 2007). Cell apoptosis caused by WSSV infection is also lower at water temperatures below $32^{\circ} \mathrm{C}$ (Granja et al. 2003). While growing shrimp at colder water temperatures poses higher risks of WSD, several farmers in the study region disregarded this due to attractive shrimp prices during cooler periods. In addition, farmers who produce $>2$ crops per year would have less time for pond drying. WSSV has been shown to remain infectious for up to $19 \mathrm{~d}$ in the sediment of a pond being sun-dried and up to $35 \mathrm{~d}$ in an undrained pond (Satheesh Kumar et al. 2013). Considering that each production cycle of Pacific white shrimp in the study area usually takes 145 to $165 \mathrm{~d}$ (including $30 \mathrm{~d}$ pre-stocking for pond preparation, 100 to $120 \mathrm{~d}$ for shrimp grow-out, and $15 \mathrm{~d}$ for post-harvest pond drying), only those farmers growing 1 or 2 crops a year can set aside adequate time for pond drying.

The multivariate regression analysis showed that the application of lime to disinfect the bottoms of fallow ponds is useful in preventing WSD, as also reported from findings in India (MPEDA/NACA 2003) and Bangladesh (Rakibul Islam et al. 2014). After each harvest, farmers usually removed the sludge pile and dried the pond bottom before applying lime, as is standard practice in shrimp aquaculture (Cruz-Lacierda et al. 2008). Farmers in the study region also applied lime at concentrations sufficient to generate a pond bottom soil $\mathrm{pH}>10$, which has proven to be an effective disinfectant (Boyd \& Massaut 1999, Boyd 2003).

The final logistic model indicated that the use of probiotic feed supplements was a preventive factor against WSD. Bacillus spp. probiotics from either commercial or government sources were used commonly in the study region. Many farmers used pineapple or banana as probiotics because they contain substantial amounts of vitamin C (Klimczak et al. 2007), which has been shown to improve stress and non-specific defense responses in shrimp (Lee \& Shiau 2002, Qiao et al. 2011). Some lactic acid bacteria have been reported to enhance growth of shrimp and fish (Kesarcodi-Watson et al. 2008, Lara-Flores 2011, Tuan et al. 2013, Aguilera-Rivera et al. 2014). Probiotics have been suggested to enhance the resistance of cultured shrimp to WSSV by mechanisms involving competitive exclusion and/or immune stimulation (Li et al. 2009). For example, probiotic organisms such as Staphylococcus hemolyticus and Pediococcus pentosaceus have been found to protect Pacific white shrimp against WSSV and infectious hypodermal and hematopoietic necrosis virus
(Leyva-Madrigal et al. 2011). However, it is possible that the use of probiotics at a farm was simply an indicator of the farmer having the financial ability to better manage crop grow-out, which might confound the survey data correlating probiotics use with lowered WSD risks.

With P. monodon, stocking ponds with WSSVinfected PL has been reported to be useful in mitigating WSD risks (Limsuwan 1997, Withyachumnarnkul 1999), and PCR screening of PL for WSSV is generally recommended for shrimp cultured in Thailand (Flegel 2012). However, PCR data on PL screened over the study period identified no correlation between WSSV detection and WSD occurring during grow-out. Other WSSV infection entry routes into ponds such as intake water or carrier species thus appear to have overridden any benefits of PL screening. While this finding supports PL screening for WSSV being non-mandatory in Thailand, our findings are unlikely to dissuade farms with the capacity to accommodate screening from continuing with this practice as part of their disease risk management strategy.

The primary findings of the shrimp farmer survey and PL testing undertaken in the Chanthaburi province study region were that the use of communal water sources by many independent farms was the major WSD risk factor. Thus, mitigating WSD needs to be a shared responsibility of shrimp farming communities using such water sources and should be supported by appropriate government incentives. The study also identified a need for farms utilizing communal water canals to exercise care with water and pond management practices, including the use of lime at concentrations adequate to disinfect the pond bottom soil during dry-out. Farms undertaking continuous culture cycles need to consider employing an adequate period for pond drying and avoiding shrimp culture during cooler months. While surveillance for WSD carriers in communal water canals and mandatory PL testing might also be considered to reduce the risks of WSD, key to the success of such measures will be the active support and participation of local shrimp farming communities.

Acknowledgements. We thank the Chanthaburi Coastal Fisheries Research and Development Centre for their assistance throughout the study. We are thankful to Professor Dirk U. Pfeiffer, The Royal Veterinary College, UK, for reviewing manuscript drafts. This study was supported by the Chulalongkorn University Graduate Scholarship to Commemorate the 72nd Anniversary of His Majesty King Bhumibol Adulyadej and the 90th Anniversary of Chulalongkorn University Fund. 


\section{LITERATURE CITED}

Aguilera-Rivera D, Prieto-Davo A, Escalante K, Chavez C, Cuzon G, Gaxiola G (2014) Probiotic effect of FLOC on Vibrios in the Pacific white shrimp Litopenaeus vannamei. Aquaculture 424-425:215-219

Boyd CE (2003) Bottom soil and water quality management in shrimp ponds. J Appl Aquacult 13:11-33

Boyd CE, Massaut L (1999) Risks associated with the use of chemicals in pond aquaculture. Aquacult Eng 20: 113-132

Corsin F, Turnbull JF, Hao NV, Mohan CV and others (2001) Risk factors associated with white spot syndrome virus infection in a Vietnamese rice-shrimp farming system. Dis Aquat Org 47:1-12

Corsin F, Turnbull JF, Mohan CV, Hao NV, Morgan KL (2005) Pond-level risk factors for white spot disease outbreaks. In: Walker $\mathrm{P}$, Lester $\mathrm{R}$, Bondad-Reantaso MG (eds) Diseases in Asian aquaculture V. Fish Health Section, Asian Fisheries Society, Manila, p 75-92

Cruz-Lacierda ER, Corre V, Yamamoto A, Koyama J, Matsuoka J (2008) Current status on the use of chemicals and biological products and health management practices in aquaculture farms in the Philippines. Mem Fac Fish Kagoshima Univ 57:37-45

Department of Fisheries (2014) Number of farms, area under culture and yield by species and province. Available at www.fisheries.go.th/it-stat/ (accessed 22 November 2014)

Dieu BTM, Marks H, Zwart MP, Vlak JM (2010) Evaluation of white spot syndrome virus variable DNA loci as molecular markers of virus spread at intermediate spatiotemporal scales. J Gen Virol 91:1164-1172

> Flegel TW (1997) Major viral diseases of the black tiger prawn (Penaeus monodon) in Thailand. World J Microbiol Biotech 13:433-442

> Flegel TW (2012) Historic emergence, impact and current status of shrimp pathogens in Asia. J Invertebr Pathol 110:166-173

Granja CB, Aranguren LF, Vidal OM, Aragón L, Salazar M (2003) Does hyperthermia increase apoptosis in white spot syndrome virus (WSSV)-infected Litopenaeus vannamei? Dis Aquat Org 54:73-78

Huang WJ, Leu JH, Tsau MT, Chen JC, Chen LL (2011) Differential expression of $L v H S P 60$ in shrimp in response to environmental stress. Fish Shellfish Immunol 30:576-582

Kesarcodi-Watson A, Kaspar H, Lategan MJ, Gibson L (2008) Probiotics in aquaculture: the need, principles and mechanisms of action and screening processes. Aquaculture 274:1-14

Klimczak I, Małecka M, Szlachta M, Gliszczyńska-Świgło A (2007) Effect of storage on the content of polyphenols, vitamin $\mathrm{C}$ and the antioxidant activity of orange juices. J Food Compos Anal 20:313-322

Lara-Flores M (2011) The use of probiotic in aquaculture: an overview. Int Res J Microbiol 2:471-478

> Lee MH, Shiau SY (2002) Dietary vitamin C and its derivatives affect immune responses in grass shrimp, Penaeus monodon. Fish Shellfish Immunol 12:119-129

Leyva-Madrigal KY, Luna-González A, Escobedo-Bonilla CM, Fierro-Coronado JA, Maldonado-Mendoza IE (2011) Screening for potential probiotic bacteria to reduce prevalence of WSSV and IHHNV in whiteleg shrimp (Litopenaeus vannamei) under experimental conditions. Aquaculture 322-323:16-22

> Li J, Tan B, Mai K (2009) Dietary probiotic Bacillus OJ and isomaltooligosaccharides influence the intestine microbial populations, immune responses and resistance to white spot syndrome virus in shrimp (Litopenaeus vannamei). Aquaculture 291:35-40

Limsuwan C (1997) Reducing the effects of white-spot baculovirus using PCR screening and stressors. AAHRI Newsl 6:1-2

Lyle-Fritch LP, Romero-Beltrán E, Páez-Osuna F (2006) A survey on use of the chemical and biological products for shrimp farming in Sinaloa (NW Mexico). Aquacult Eng 35:135-146

Mohan CV, De Silva SS (2010) Better management practices (BMPs) - gateway to ensuring sustainability of small scale aquaculture and meeting modern day market challenges and opportunities. Aquacult Asia 15:9-14

Mohan CV, Phillips MJ, Bhat BV, Umesh NR, Padiyar PA (2008) Farm-level plans and husbandry measures for aquatic animal disease emergencies. Rev Sci Tech 27: 161-173

MPEDA/NACA (Marine Products Export Development Authority/ Network of Aquaculture Centres in the AsiaPacific) (2003) Shrimp health management extension manual. Prepared by the Network of Aquaculture Centres in the Asia-Pacific, in cooperation with the Aquatic Animal Health Research Institute, Bangkok, Thailand, Siam National Resources, Bangkok, Thailand, and AusVet Animal Health Services, Australia. The Marine Products Export Development Authority, Cochin

Nunan LM, Arce SM, Staha RJ, Lightner DV (2001) Prevalence of infectious hypodermal and hematopoietic necrosis virus (IHHNV) and white spot syndrome virus (WSSV) in Litopenaeus vannamei in the Pacific ocean off the coast of Panama. J World Aquacult Soc 32:330-334

OIE (World Organization for Animal Health) (2014) Manual of diagnostic tests for aquatic animals 2014. Available at www.oie.int/fileadmin/Home/eng/Health_standards/aahm/ current/2.2.06_WSD.pdf (accessed 15 December 2014)

Padiyar P, Phillips M, Primphon M, Mohan C and others (2003) Extension in shrimp health management: experiences from an MPEDA/NACA program in Andhra Pradesh, India. Aquacult Asia 8:7-13

> Peeler EJ, Taylor NGH (2011) The application of epidemiology in aquatic animal health - opportunities and challenges. Vet Res 42:94

Phan LT, Bui TM, Nguyen TTT, Gooley GJ and others (2009) Current status of farming practices of striped catfish, Pangasianodon hypophthalmus in the Mekong Delta, Vietnam. Aquaculture 296:227-236

Qiao J, Du ZH, Zhang YL, Du H and others (2011) Proteomic identification of the related immune-enhancing proteins in shrimp Litopenaeus vannamei stimulated with vitamin C and Chinese herbs. Fish Shellfish Immunol 31:736-745

Rakibul Islam HM, Khan MH, Roy D, MahmudulAlam M and others (2014) Association of risk factors: WSSV proliferation in the shrimp (Penaeus monodon) farms of south-west coastal region of Bangladesh. Ann Vet Anim Sci 1:39-51

> Reyes A, Salazar M, Granja C (2007) Temperature modifies gene expression in subcuticular epithelial cells of white spot syndrome virus-infected Litopenaeus vannamei. Dev Comp Immunol 31:23-29

Satheesh Kumar S, Ananda Bharathi R, Rajan JJS, Alavandi SV, Poornima M, Balasubramanian CP, Ponniah AG (2013) Viability of white spot syndrome virus (WSSV) in sediment during sun-drying (drainable pond) and under 
non-drainable pond conditions indicated by infectivity to shrimp. Aquaculture 402-403:119-126

Tuan TN, Duc PM, Hatai K (2013) Overview of the use of probiotics in aquaculture. Int $\mathrm{J}$ Res Fish Aquacult 3:89-97

Tendencia EA, Bosma RH, Verreth JAJ (2010) WSSV risk factors related to water physico-chemical properties and microflora in semi-intensive Penaeus monodon culture ponds in the Philippines. Aquaculture 302:164-168

Tendencia EA, Bosma RH, Verreth JAJ (2011) White spot syndrome virus (WSSV) risk factors associated with shrimp farming practices in polyculture and monoculture farms in the Philippines. Aquaculture 311:87-93

Umesh NR, Chandra Mohan AB, Padiyar PA, Phillips MJ, Mohan CV, Vishnu Bhat B (2010) Shrimp farmers in India: empowering small-scale farmers through a clusterbased approach. In: De Silva SS, Davy FB (eds) Success stories in Asian aquaculture. Springer, London, p 41-66

Editorial responsibility: Jeff Cowley, Brisbane, Queensland, Australia
Vidal OM, Granja CB, Aranguren F, Brock JA, Salazar M (2001) A profound effect of hyperthermia on survival of Litopenaeus vannamei juveniles infected with white spot syndrome virus. J World Aquacult Soc 32:364-372

Vijayan KK, Sanil NK (2012) Introduction to exotics and trans-boundary movement of aquatic organisms: policy requirements and relevance to Indian aquaculture in the post-WTO scenario. Available at http://eprints.cmfri. org.in/9076/ (accessed 25 December 2013)

Withyachumnarnkul B (1999) Results from black tiger shrimp Penaeus monodon culture ponds stocked with postlarvae PCR-positive or -negative for white-spot syndrome virus (WSSV). Dis Aquat Org 39:21-27

Withyachumnarnkul B, Boonsaeng V, Chomsoong R, Flegel TW, Muangsin S, Nash GL (2003) Seasonal variation in white spot syndrome virus-positive samples in broodstock and post-larvae of Penaeus monodon in Thailand. Dis Aquat Org 53:167-171

Submitted: April 29, 2015; Accepted: September 13, 2015 Proofs received from author(s): November 7, 2015 